\title{
THE REPRESENTATION OF THE SERPENT IN ANCIENT IBERIA
}

\section{Margarita Bru Romo - Ana Vazquez-Hoys}

In Ancient Iberia, the use of the serpent as a symbol began before the settlements of the Phoenicians, Greeks and Carthaginians and before the first waves of the Indoeuropean peoples. There is no doubt that it had the same sacred character as it did in most ancient cultures. We intend to give a summary of these representations from this early age to the Roman Period.

As we said, we find a cult to the serpent in Iberian Prehistory and Protohistory. Serpentine lines similar to those found in megalithic dolmens of Bretagne and Ireland appear in Spain and Portugal (Shee 1974: 105-123), but the representation of the snake is clearer from the Final Bronze Age onwards.

At that time two parallel events took place in Iberia: the coming of Indoeuropean Cultures from Europe and the first contacts with historic peoples from the Eastern Mediterranean. Both events, together with the peninsular substratum, generated a number of cultures in which either Celtic or oriental elements predominated. The Celtic influence can be seen especially in the North West. The oriental one produced Tartessic culture and Iberian Art, the first in Western and the second in Eastern Andalucia and along the Eastern Coast (Almagro Bachs - Almagro Gorbea 1976: 177). Anyhow, in all these cultures the serpent is present, either as a symbol of Life and Fertility or of Death and Immortality.

First, we shall draw attention to some pieces coming from the North West of Spain. In the Citania of Troia (Pericot 1953: 3) there is a serpent engraved on a previously levelled face of a rock. This serpent allows López Cuevillas (López Cuevillas - Bouza Brey 1920: 168) to affirm, on commenting Ávienos' Ora Maritima, that there was a similarity between Celtic beliefs and those of an earlier, probably autochthonous people.

The ex-voto from Castelo de Moreira (Galicia) represents a sacrificial scene: a pig, a goat and two sheep walking on a line formed by four twisted bronze strings. On the reverse there is a basket or vase, a human torso and the front part of a serpent which can be either an apotropaic element or the Divinity to whom the sacrifice is dedicated 
(López Cuevillas 1958: 160). Another ex-voto similar in shape in the National Archaeological Museum presents the snake in relation to the bull.

A bronze serpent with a triangular head and well defined eyes and mouth has been found at "El Palao"(Teruel). It can also be an ex-voto coming from a nearby sanctuary. Some stelae were also found; they are framed with serpentine lines similar to those in megalithic tombs. Some of these lines are more like floral stylizations but some of the decorative elements of the stelae (such as the hand, the animals and the rider's spear) are in an inverted position. This seems to point to some kind of magic ritual a part of which would be the serpent.

Serpents represented by broken lines like those mentioned above, also appear in some other stelae from Navarra and Burgos (Marco 1976: 76; 1978: 44; 1980: 149). In others the serpent frames a round graphic campus, now and then becoming a floral stylization or a twisted cord which ends in horses' heads: Nevertheless, it is evident that the element is the same.

The serpent represented as a vegetal stylization can be seen as well in the cup from Tivissa (Raddatz 1969: 90). According to some interpretations (Neumann 1955: 39) this time it might be a masculine sexual symbol.

The symbol of the serpent in the Phoenician world and its relationship with fertility and survival is obvious. In Ancient Iberia we find metal jars - Niebla, Siruela, Metropolitan Museum, Lazaro Galdeano's Museum, Villanueva de la Vera, La Joya, etc - of Phoenician type also decorated with serpents. J.M. Blázquez and J.P. Garrido believe that these jars come from Spanish workshops having strong Phoenician influence (Garrido Roig 1970).

Among Tartessian jewellery, most remarkable is a golden necklace with two pendants in the shape of a snake's head. The necklace comes from the tomb of a woman and belongs to the Aliseda treasure. The decoration is quite oriental but no exact parallel is known (Blanco Frejeiro 1956: 3). Two other pendants are spheres which may represent pomegranates; these together with the serpent's head would point to fertility symbolism.

The belt buckles of the so-called "Celtic belts", because some were found on sites of Celtiberian influence, have an oriental origin. The plaques of the belts have stylized feminine forms similar to megalithic idols; they hook into metallic serpentine terminals or into others truly 
like serpents, with clearly defined heads and tails (Pl. 37). The union of both elements, woman or goddess and snake, is an obvious reference to fertility. The pieces from La Joya (Huelva), Cerro de Huerta Ripoll (Córdoba), and Acebuchal (Sevilla) are well known items (Morán Cabré 1973: 597; 1977: 611).

Torques and bracelets with snake-like terminals are common not only in the Mediterranean but also in central Europe. Among the first we should remember the necklace from Chao de Lamas, in Portugal. Raddatz relates two bracelets from Villanueva de Córdoba (Jaén) with others found in South Germany and Italy, dated in an advanced La Téne Period. Bracelets and necklaces with snake-like terminals might be just a fashion in Mediterranean cultures.

We have already met snakes related to the bull-cult. At Reillo (Cuenca) it appears related to the ram (Maderuelo - Pastor 1981: 161183). There is an andiron in the shape of a ram with four snakes on its back which, along with some pottery also with serpentine decoration, might point towards a fertility cult among cattle-breeding people at this site.

In some ceramic pieces of the Iberian culture the snake can be seen in association with the Tree of Life, the deer (instead of the Mesopotamian goat), the frog, fish or with astral symbols. In Azaila (Teruel) it appears near a very stylized Tree of Life running after a frog (Pl. 38). Nearby another frog is eating a snake. It should be noticed that both are aquatic creatures (Lucas 1979: 241).

At the Museum of Jaen there are two anthropomorphic figures with snakes on their backs which lean their heads on the figures'chest. Another one has a serpent along its left arm which is not visible when the figure is seen from the front (Ruano 1983: 54). The famous Iberian sanctuaries of Despeñaperros are near the area in which the statuettes have been found. There also are plenty of thermal springs, so the figures might be easily related either to fertility or health, or might belong to a funeral monument (Blázquez 1983: 426) similar to that of Pozo Moro. At Pozo Moro we also find the serpent, this time forming the end of the tail of a chimaera (Almagro Gorbea 1975: 671).

In Ancient Iberia, the representation of the serpent is rare in works connected with the Greek world. Apart from the Asklepios in the Archaeological Museum of Barcelona and the ex-voto from Mallorca (Garcia Bellido 1948: 127-130) there is little to be mentioned.

In connection with the Roman world t'le serpent appears in objects of a very different type. There is, of course, the traditional 
Esculapius' serpent; we have some arae dedicated to him. In the small votive arae found in Italica (Martínez Munilla 1950:208), now in the Museum of Seville, Esculapius' serpent appears together with a pinecone, another of his attributes; there are two other arae in Barcelona, a beautiful one coming from Carthago-Nova(Beltrán 1947:213) and the painted ara from Ampurias (Nieto Prieto 1971: 385). There is also the traditional Mithras' serpent: we should mention the two pieces in the Mithraeum of Merida, the Aion and the beautiful figure which has been recently identified as Mithra saxigenus (Bendala Galán 1979: 285). There are some golden rings, two in the Museum of Córdoba and one in the Museum of Huelva. The serpent also accompanies the headless Minerva and the beautiful pondus of the National Archaeological Museum. Obviously, it also appears in Mercury's caduceus (García Bellido 1949: 137, 180 and 452).

In other pieces the meaning of the serpent is not so clear. In the ara of Altea it is shown together with a pigeon and a pomegranate (Pl. 39) (Fita 1908: 375); in a piece of entablature it can be seen pursuing a frog as it does in the ceramics from Azaila already mentioned; as the symbol of Tellus, the fertile Earth, the serpent appears in the trulla of Castulo (Blanco Frejeiro 1961: 93); the feminine figure of the so-called Casa de Pilatos in Seville may represent Hygias though it seems to have been very badly restored; in the Voconios' stela from Mérida the two serpents may allude to the bracelets given as rewards to soldiers Bendala Galán 1972: 240). The bracelets might also have an apotropaic quality suggested by their serpent-like shape.

The last piece we would like to mention comes from the Roman city of Ercavica and it is in the Museum of Cuenca. It is a headless torso with a small serpent advancing along the body and a bigger serpent which seems to hang around the neck with its head and tail on the torso's back. It is known as the Aion of Ercavica but it is evident that the figure has two serpents and their position is peculiar enough to question such identification.

It seems that the most popular divinities in Ancient Iberia during the Roman period were those related to Fertility cults. Judging by the remains (inscriptions, coins, monuments), Diana and Venus were especially venerated in the East part of the Peninsula, while other deities were worshipped in the rest of the country. Some gravestones dedicated to Venus have been found in the Mediterranean coast; in these, Venus might be identified either with a chthonic aspect of the goddess or with some other goddess such as Demeter, Tanit, etc (Vázquez Hoys 1983: 311). 
The already mentioned ara of Altea shows a pigeon, a serpent and a pomegranate in its decoration. This seems to point to an identification between funeral and fertility deities. Fita assumes that the pigeon - Columba - is the name of the dead woman; we suggest that its association with the serpent and the pomegranate rather points to a chthonic-fertility goddess. On the other hand the cult of Adonis and that of the Magna Mater continue in Sevilla up to the 3rd century and the cult of Hercules in Cádiz up to the 4th.

This might lead one to think that in Ancient Iberia pre-Roman people remained rather resilient to Roman cults. Because of their being so deeply rooted in the Punic and oriental worlds they seem to have a preference for those deities who could incarnate, above all, the old oriental goddesses.

It is evident that the serpent as a symbol has been used by cultures all over the world. Its persistence throughout the ages is impressive.

In Mesopotamia and in pre-Arian India, even in the magnificent bowls from Susa of the Vth millennium, the snake appears related to Water as a source of Life and Fertility. It also appears related to Death as part of the vital cycle of reproduction. Later on its symbolism becomes more complex and the snake can be found as guardian of the Dead, of Homes and of treasures. Nilsson (Nilsson 1941: 184) contemplates the possibility of its identification with the dead person turned into a hero. What is its meaning when it appears coiled around the Tree of Life advancing its head towards the Thracian horseman? In the Roman period according to Plinius, Ovidius and Elienus the spine of the dead person changed into a snake. Besides its funeral character the snake appears as founder of cities and begetter of heroes (Cumont 1949: 17). The serpent also has guessing and healing powers (Dumezil 1966: 496). It appears also with Mithra, as symbol of the generative power of Earth.

If we compare different proverbs, legends and tales, we can see that serpents appear either as kind and propitious animals, fiercely loyal to their masters, or as carriers of sorrow and death. Aristoteles (Bodson 1978: 78) in his History of Animals proposes to classify them by the different types of their psychology. According to him, the serpent seems to be a repulsive, evil and terrible creature. Moreover, not only in Greece but in most other countries people have always had ambivalent and contradictory experiences with snakes. This characteristic ambiguity has precisely been the one that has made possible the identification of the serpent with the numinous and the 
sacred since ancient times: as gods they inspire awe and can also be good and propitious; as gods serpents eat honey because of its youthrestoring qualities; serpents as gods have an aura of immortality (Vázquez Hoys 1981: 33).

The exact meaning of every single representation of the serpent in Ancient Iberia is difficult to determine. The meaning might be different or there might not be any meaning at all: the goldsmith or the sculptor may have just intended to copy a motif which was fashionable at the time. Nevertheless if we think that up to a few years ago, in some villages of the North-West of Spain, the skin of a snake was put on the womb of women in labour to propitiate the birth, it seems likely that in spite of its apparent ambivalence and in spite of the cultivated myths of the Classical Era, the serpent has maintained through the centuries its original association with Water and Fertility Goddesses.

\section{Summary}

We find a cult to the serpent in Iberian Prehistory and Protohistory. Indoeuropean and Mediterranean cultures adopted this cult which had similarities with the beliefs of an earlier people, probably autochthonous. Different ex-votos, Phoenician metal jars, the so-called "Celtic belts", Tartessian jewellery, Iberian pottery, etc., decorated with snakes prove this assertion.

In the Roman period the serpent appears in objects of a very different type and, most times, though it may seem just a fashionable decoration it also has an apotropaic or fertility meaning, as in the case of the ara of Altea or Voconio's stela. This meaning is still present in the beliefs of some peasant villages.

\section{Résumé}

Il existe un culte au serpent dans la préhistoire et protohistoire de l'ancienne Ibérie. Les cultures indo-européennes et méditerranéennes introduisirent ce culte qui était semblable aux croyances des peuples précédents, probablement autochtones. Il y a de différents ex-votos, des brocs phéniciens en métal, les dites "ceintures celtiques", l'orfêvrerie de l'ancienne Tartesse, la céramique Ibère, etc., tous décorés de serpents qui prouvent cette affirmation. 
Dans la période romaine, le serpent apparaît sur des pièces d'un type très different et la plupart du temps, même s'il semble être tout simplement une décoration à la mode, il présente aussi un aspect apotropaique ou de fertilité qui apparaît aussi sur l'autel d'Altea et sur la stèle des Voconios. Cet aspect est encore présent dans les croyances de quelques peuples de l'Espagne agricole. 


\section{Bibliography}

ALMAGRO BACHS, M. - ALMAGRO GORBEA, M.

1975 - Pozo Moro y el origen del Arte Ibérico CAN XIII, 671.

1976 - Resistencia y asimilación de elementos culturales del Mediterráneo oriental en Iberia prerromana. Assimilation et résistence à la culture gréco-romaine dans le monde ancien préromain, Paris,

ALMAGRO GORBEA, M.

1977 - El Bronce final y el periodo orientalizante en Extremadura, Madrid.

BELTRAN, A.

1947 - El ara del Museo de Barcelona y su relación con el culto de la Salud y Esculapio en Cartagonova, Ampurias IX-X, 49.

BENDALA GALAN, $M$.

1972 - Los llamados columbarios de Mérida, Habis 3, p. 240 lám 5 fig. 12

1979 - Las religiones mistéricas en la Espana romana, Symposio sobre la Religión romana en Hispana, Madrid.

BLANCO FREJEIRO, A.

1956 - Orientalia. Estudio de los objetos fenicios y orientalizantes en la Península, $A E A$ XXXIX.

1961 - Un interesante fragmento cerámico del Museo arqueológico de Linares, Oretania 8-9.

BLAZQUEZ, J.Ma.

1975 - Tartessos II, Universidad de Salamanca.

BODSON, L.

1978 - Contribution à l'etude de la place de l'animal dans la religion grecque ancienne, Bruxelles.

CUMONT, F.

1942 - Recherches sur le symbolisme funéraire des romains, Paris.

1949 - Lux Perpetua, Paris.

DUMEZIL, G.

1966 - La Religion romaine archaïque, Paris.

FITA, F.

1908 - El ara de Altea, $B A H 52$.

GARCIA BELLIDO, A.

1948 - Hispana Graeca II, Barcelona.

1949 - Esculturas romanas de Espana y Portugal, Madrid.

GARRIDO ROIG, J.

1970 - Excavaciones en la Necrópolis de La Joya, $A E A$ LXXI. 
GOMEZ MORENO, M. - SANCHEZ PIJOAN, J.

1912 - Materiales de Arqueología espanola, Madrid.

LOPEZ CUEVILLAS, F. - BOUZA BREY, F.

1920 - Os Oestrimnios, os Saefes e a Ofiolatria en Galiza, Arquivo de Seminario de Estudos Galegos, II.

LOPEZ CUEVILLAS, F.

1958 - La civilización céltica en Galicia, Santiago de Compostela.

LUCAS, R.

1979 - La decoración figurada en la pintura vascular, Actas Mesa Redonda sobre la Baja Epoca Ibérica, Madrid.

MADERUELO, $\mathrm{M}$.

1981 - Excavaciones en Reillo (Cuenca), $N A H 12$,

MARCO, F.

1976 - Nuevas estelas ibéricas en Alcaniz, Pyrenae XII, 1976, pp. 76 ss.

1978 - Estelas decoradas de los Conventos Cesaraugustano y Cluniense, Caesaraugusta 43-44.

1980 - Excavaciones en "El Palao"(Alcaniz, Teruel), Caesaraugusta 5152.

MARTINEZ MUNILLA, C.

1950 - Sobre un ara de Itálica, $A E A 23$,

MORAN CABRE, J.

1973 - Sobre el carácter votivo y apotropaico de los broches de cinturón en la Edad del Hierro Peninsular, XIII $C A N$, Huelva.

1977 - La exponencia femenina y la signografía ofídica en broches de cinturón del Hierro hispánico, XIV $C A N$, Zaragoza.

NEUMANN, E.

1955 - The Great Mother. Analysis of the Archetype, Princeton.

NIETO PRIETO, F.J.

1971-1972 - Ara pintada de Ampurias dedicada a Esculapio, Ampurias XXXIII-XXXIV.

NILSSON, H.P.

1941 - Geschichte der Griechischen Religion, Munich.

PERICOT, L.

1953 - La representación serpentiforme de la citania de Troia, $A E A$ XXVI.

RADDATZ, $\mathrm{K}$.

1969 - Die Schatzfunde der Iberischen Halbinsel, Berlin, Madrider Forschungen. Band 5. Deutsches Archäologisches Institut Abteilung. Madrid, pls. 1 n. 1;3 n. 3,5;6 n. 9, 12, 13, 14;25 n. 3 y 6; 27 n. $3 ; 28$ n. $1 ; 32$ n. $5 ; 36$ n. $4,5,6 ; 38$ n. 3 y $4 ; 39$ n. $1 ; 40$ n. $3 ; 44$ n. $3 ; 52$ n. $1,3,8,9,10 ; 53$ n. $4 ; 56$ n. $1 ; 60$ n. $2 ; 63-63 ; 72$ n. 5,$7 ; 83$ n. 2 y $3 ; 93$ n. 2 . Also pl. 90 . 
RUANO, E.

1983 - Panorama de la escultura ibérica en Andalucïa, Bol. Asoc. Amigos Arqueología 17.

SHEE, E.

1974 - Painted Megalithic Art in Western Iberia, Actas III Congreso Arqueológico Nacional, vol. I.

VAZQUEZ HOYS, A. Ma.

1981 - La serpiente en el mundo antiguo I. La serpiente en las religiones mediterráneas, Bol. Asoc. Arqueología 14.

1983 - Sobre la Diana de Segóbriga, Homenaje al Profesor D. Martin Almagro Bachs III, Madrid. 